\title{
A replacement name for Agasthenes Bates, 1873 (Coleoptera:Tenebrionidae), junior homonym of Agasthenes Förster, 1869 (Hymenoptera: Ichneumonidae)
}

\author{
John Ponting \\ 26 Slepe Crescent, Poole, Dorset BH12 4DN, United Kingdom. \\ Email: wam2018@phalangium.org.uk
}

KEYWORDS: beetles, taxonomy, wasps

urn:Isid:zoobank.org:pub:0EE3E1B6-F09E-4970-8544-A6B682904994

In 1869 Förster described a subgenus of the genus Hemiteles (Hymenoptera, Ichneumonidae) and gave it the name Agasthenes Förster, 1869. Subsequently, it was raised to the rank of genus and the subgenus Asthenoptera Förster, 1869 and the genus Arachnoleter Cushman, 1924 were synonymised under it. There are currently five species in this genus (Yu 2018): Agasthenes angustus Townes, 1983 (from North America); Agasthenes fulvibasis Townes, 1983 (from North America); Agasthenes subarcticus (Jussila, 1965), originally in the genus Hemiteles Gravenhorst, 1829 (from northern Europe); Agasthenes swezeyi (Cushman, 1924), originally in the genus Arachnoleter Cushman, 1924 (from Asia and North America); and Agasthenes varitarsus (Gravenhorst, 1829), originally in the genus Hemiteles Gravenhorst, 1829 (from northern and central Europe). The type species of the genus is Hemiteles varitarsus Gravenhorst, 1829.

In 1873 Bates described a genus of tenebrionid beetle from Australia, naming it Agasthenes Bates, 1873. This genus originally contained just a single species, Agasthenes westwoodi Bates, 1873, which is therefore the type species of this genus by monotypy. Carter (1909, 1910, 1937) subsequently described a further six species in this genus: Agasthenes goudiei Carter, 1909, now synonymised under Amphianax subcoriaceus Bates, 1873; Agasthenes stepheni Carter, 1909, now Nyctozoilus stepheni (Carter, 1909) [nec Carter, 1914]; Agasthenes euclensis Carter, 1910, subsequently synonymised under $A$. goudiei Carter, 1909 and thence to Amphianax subcoriaceus Bates, 1873; Agasthenes tepperi Carter, 1937, now Nyctozoilus tepperi (Carter 1937); Agasthenes frenchi Carter, 1909; and Agasthenes championi Carter, 1910.
Therefore Batessia nomen novum (ZooBank Registration: urn:1sid:zoobank.org:act:0A9744224FB3-4A1F-AFCE-46545D2E9B3E) is proposed here as a replacement name for Agasthenes Bates, 1873, preoccupied by Agasthenes Förster, 1869 (Hymenoptera). The name honours the person who described the original genus, with the second 's' added to avoid homonymy with Batesia Felder \& Felder, 1862 (Lepidoptera). The gender is feminine. Batessia contains three species: Batessia westwoodi (Bates, 1873) comb. nov., Batessia frenchi (Carter, 1909) comb. nov. and Batessia championi (Carter, 1910) comb. nov. The type species, in accordance with Article 67.8 of the International Code of Zoological Nomenclature, is Agasthenes westwoodi Bates, 1873.

\section{REFERENCES}

Bates, F. (1873). Descriptions of new genera and species of Tenebrionidae from Australia, New Caledonia and Norfolk Island. Transactions of the Entomological Society of London 1873: 347-380.

Carter, H.J. (1909). Notes on Australian Coleoptera: with descriptions of new species of Tenebrionidae. Proceedings of the Linnean Society of New South Wales 34(133): 120-156.

Carter, H.J. (1910). Revision of Sympetes and Helaeus: with descriptions of new species of Tenebrionidae [Coleoptera]. Proceedings of the Linnean Society of New South Wales 35(137): 77-134.

Carter, H.J. (1937). Some new Tenebrionidae in the South Australian Museum; together with notes and descriptions of other Australian Coleoptera. Transactions of the Royal Society of South Australia 61: 121-144.

Förster, A. (1869). Synopsis der Familien und Gattungen der Ichneumonen. Verhandlungen des Naturhistorischen 
Vereins der Preussischen Rheinlande und Westfalens 25(1868): 135-221.

Felder, C. \& Felder, R. (1862). Specimen faunae lepidopterologicae riparum fluminis Negro superioris in Brasilia septentrionali. Wiener entomologische Monatsschrift 6: 109-126

International Commission on Zoological Nomenclature (1999). International Code of Zoological Nomenclature, fourth edition. International Trust for Zoological Nomenclature: London.
Yu D.S.K. (2018). Taxapad Ichneumonoidea (version May 2009). In: Species 2000 \& ITIS Catalogue of Life, 2018 Annual Checklist (Roskov Y., Abucay L., Orrell T., Nicolson D., Bailly N., Kirk P.M., Bourgoin T., DeWalt R.E., Decock W., De Wever A., Nieukerken E. van, Zarucchi J., Penev L., eds.). Digital resource at www.catalogueoflife.org/annual-checklist/2018. Species 2000: Naturalis, Leiden, the Netherlands. [accessed 26 June 2018].

MANUSCRIPT RECEIVED 27 JUNE 2018; ACCEPTED 2 JULY 2018. 